\title{
Habitat associations of small mammals in southern Brazil and use of regurgitated pellets of birds of prey for inventorying a local fauna
}

\author{
Scheibler, DR. ${ }^{\mathrm{a} *}$ and Christoff, $A U \mathrm{.}^{\mathrm{b}, \mathrm{c} *}$ \\ aDepartamento de Zoologia, Universidade Estadual Paulista - UNESP, Av. 24A, CEP 13506-900, Rio Claro, SP, Brazil \\ ${ }^{\text {b}}$ Departamento de Zoologia, Universidade Federal do Rio Grande do Sul - UFRGS, \\ Av. Bento Gonçalves, CEP 91501-970, Porto Alegre, RS, Brazil \\ 'Departamento de Biologia e Museu de Ciências Naturais, Universidade Luterana do Brasil - ULBRA, \\ Av. Farroupilha, 8001, Bairro São José, CEP 92450-900, Canoas, RS, Brazil \\ *e-mail: sdaniel_ricardo@hotmail.com, auchrist@ulbra.br
}

Received June 1, 2005 - Accepted April 19, 2006 - Distributed November 30, 2007

\begin{abstract}
We inventoried terrestrial small mammals in an agricultural area in southern Brazil by using trapping and prey consumed by Barn Owls (Tyto alba) and White-tailed Kites (Elanus leucurus). Small mammals were trapped in three habitat types: corn fields, uncultivated fields ("capoeiras"), and native forest fragments. A total of 1,975 small mammal specimens were trapped, another 2,062 identified from the diet of Barn Owls, and 2,066 from the diet of White-tailed Kites. Both trapping and prey in the predators' diet yielded 18 small mammal species: three marsupials (Didelphis albiventris, Gracilinanus agilis, and Monodelphis dimidiata) and 15 rodents (Akodon paranaensis, Bruceppatersonius iheringi, Calomys sp., Cavia aperea, Euryzygomatomys spinosus, Holochilus brasiliensis, Mus musculus, Necromys lasiurus, Nectomys squamipes, Oligoryzomys nigripes, Oryzomys angouya, Oxymycterus sp.1, Oxymycterus sp.2, Rattus norvegicus, and Rattus rattus (Linnaeus, 1758)). The greatest richness was found in the uncultivated habitat. We concluded that the three methods studied for inventorying small mammals (prey in the diet of Barn Owls, Whitetailed Kites, and trapping) were complementary, since together, rather than separately, they produced a better picture of local richness.
\end{abstract}

Keywords: inventory, richness, small mammals, agroecosystems, southern Brazil, Tyto alba, Elanus leucurus.

\section{Associações de habitat de pequenos mamíferos no sul do Brasil e uso de pelotas de regurgitação de aves de rapina para inventariar uma fauna local}

\section{Resumo}

Nós inventariamos a fauna de pequenos mamíferos terrestres numa área agrícola no sul do Brasil utilizando armadilhas e presas consumidas pela coruja suindara (Tyto alba) e pelo gavião-peneira (Elanus leucurus). Os pequenos mamíferos foram amostrados em três tipos de habitat: cultivos de milho, capoeiras e fragmentos de floresta nativa. Ao todo, 1975 espécimes de pequenos mamíferos foram capturados com armadilhas, 2062 identificados a partir da dieta da suindara e 2066 da dieta do gavião-peneira. Juntas, as capturas com armadilhas e presas identificadas na dieta de ambos os predadores revelaram 18 espécies de pequenos mamíferos: três marsupiais (Didelphis albiventris, Gracilinanus agilis e Monodelphis dimidiata) e 15 roedores (Akodon paranaensis, Bruceppatersonius iheringi, Calomys sp., Cavia aperea, Euryzygomatomys spinosus, Holochilus brasiliensis, Mus musculus, Necromys lasiurus, Nectomys squamipes, Oligoryzomys nigripes, Oryzomys angouya, Oxymycterus sp.1, Oxymycterus sp.2, Rattus norvegicus e Rattus rattus). A maior riqueza de espécies foi encontrada nas capoeiras. Nós concluímos que os três métodos estudados para inventariar a fauna de pequenos mamíferos (presas na dieta da suindara, do gavião-peneira e capturas com armadilhas) foram complementares, pois juntos forneceram uma idéia melhor da riqueza local do que individualmente.

Palavras-chave: inventário, riqueza, pequenos mamíferos, agroecossistemas, sul do Brasil, Tyto alba, Elanus leucurus.

\section{Introduction}

Inventories and biogeographical studies of small mammals have been carried out almost exclusively by means of trapping. Although the identification of prey species from the diet of carnivores or birds of prey can be used to determine the local richness of their prey, there

are few studies assessing the richness of small mammals by using and comparing species identified from the diet of predators with those trapped (Jaksić et al., 1981, 1999; Bonvicino and Bezerra, 2003). Predators could have some advantages over the traditional method for inven- 
torying small mammals, preying, for instance, on rare species or those sampled by traps with difficulty due to specific microhabitat requirements or behavioral traits.

The Barn Owl (Tyto alba (Scopoli, 1769)) is a cosmopolitan nocturnal bird of prey that hunts mainly in fields (Fast and Ambrose, 1976; Bellocq, 1990, 2000). It preys primarily on small mammals (Jaksić et al., 1982; Marti, 1988; Bellocq, 2000). The White-tailed Kite (Elanus leucurus (Vieillot, 1818)) is a diurnal bird of prey distributed throughout the Americas (Dunk, 1995). This kite is also a small mammal specialist, hunting in open environments such as fields and savannas (Mendelsohn and Jaksić, 1989; Dunk, 1995).

Fossilized mammalian prey remains, regurgitated by Barn Owls, have been used for paleontological studies, making it possible to comprehend the ecology and composition of extinct small mammal communities (e.g., Pardiñas et al., 2000; Castillo et al., 2001). Also, prey consumed by living Barn Owls have been used to discuss current local faunas of small mammals (Jaksić et al., 1981, 1999; Bonvicino and Bezerra, 2003). Clark and Bunck (1991) studied changes in the structure of small mammal communities in North America during the past several decades by using only Barn Owl pellet samples. Mammalian prey species consumed by Whitetailed Kites, on the other hand, have not been used for these purposes.

The diversity and ecology of the small mammal communities in the southernmost Brazilian state of Rio Grande do Sul, are little known and only recently some ecological studies have been undertaken (Cademartori et al., 2004; Dalmagro and Vieira, 2005). Here, our objectives were to: (1) evaluate the habitat associations of small mammals in an agricultural area of this state; and (2) inventory small mammal species based on prey found in the diet of Barn Owls and White-tailed Kites and to compare these results with trapped samples of small mammals from the same site. The food habits of Barn Owls and White-tailed Kites in this agricultural area have been discussed elsewhere (Scheibler et al., 2001; Scheibler, 2004; Scheibler and Christoff, 2004). Here, their diets are examined only from the point of view of methods for sampling small mammal species.

\section{Material and Methods}

\subsection{Study area}

The study area $\left(29^{\circ} 35^{\prime} \mathrm{S}\right.$ and $\left.52^{\circ} 12^{\prime} \mathrm{W}\right)$ was located near Venâncio Aires, Rio Grande do Sul State, southern Brazil. Topography is relatively flat (approximately $50 \mathrm{~m}$ elevation). Climate is subtropical-humid, with the mean annual temperature ranging between 18 and $20{ }^{\circ} \mathrm{C}$. The average annual rainfall of about $1,700 \mathrm{~mm}$ is evenly distributed throughout the year. The original vegetation of deciduous seasonal forest is quite reduced today, having been replaced by agriculture. For more details on relief, climate, and vegetation see Brasil (1986). The present landscape is a mosaic of vegetation types, prevailing crop fields of annual cultures such as tobacco, bean, and cassava. However, corn crops prevail widely. Other important vegetation type is locally known as "capoeira", an uncultivated environment of secondary growth composed mostly of grasses and shrubs of Baccharis spp. Based on personal recognition, approximately $70 \%$ of the study area corresponds to crop fields, followed by "capoeiras" (approximately 20\%). The remaining area consists mainly of small fragments of the native forest, eucalyptus plantations, small swamps, and cattle pasture.

\subsection{Sampling and analysis}

In November 1999, we collected small mammal remains regurgitated by Barn Owls from six nests. These remains were accumulated forming a pile of old fragmented pellets in and around nests. We do not know when they were regurgitated nor if the six nests correspond to six different years.

We gathered 1,152 pellets of White-tailed Kites collected from December 1997 through March 1999, from August 1999 through July 2000, and from October 2000 through November 2000. Pellets were collected mainly from two pairs of kites; however, we do not know if the pellets came from the same individuals.

Additionally, during October 2001 we collected 62 pellets of another two pairs of White-tailed Kites and 71 of other Barn Owls (from one nest).

We identified the small preyed mammals based on cranial structures, primarily from the morphological pattern of teeth, which were compared with a reference collection of small mammals. For Barn Owls, we had mostly a mixture of osteological remains belonging to several mammalian prey. In this case, only the right and left upper maxillaries (hemimaxillas) were used for identification because the distinction between adults of two rodent species, Akodon paranaensis Christoff, 2000 and Necromys lasiurus (Lund, 1840), was only possible based on the incisive foramen position, due to great molar tooth wear. This structure is only found on the upper maxillaries. For more methodological details on sampling and prey analysis for both predators see Scheibler et al. (2001), Scheibler (2004), and Scheibler and Christoff (2004).

We obtained trapping information in cultivated and uncultivated fields from a series of studies on the ecology and natural history of small mammals initiated in 1999. Each study had its own protocol and sampling methods and Table 1 summarizes the main information for each site sampled. Additionally, during January and February 1998 and January 2002, we live-trapped small mammals in three small fragments $(<1$ ha) of the native forest for a total of 443 trap nights. In the forest, traps were placed $10 \mathrm{~m}$ apart as line transects. In all vegetation types (crop fields, uncultivated fields, and native forest fragments) live and snap traps were placed on the ground and baited with a mixture of peanut butter and sardines. Snap traps killed small mammals of approximately the same size range sampled by live traps. 
Table 1. Sampling effort and characteristics of cultivated fields (CF) and uncultivated fields (UF) used to inventory small mammal species in Venâncio Aires, Rio Grande do Sul state, southern Brazil. All CFs were cornfields.

\begin{tabular}{|c|c|c|c|c|}
\hline Site & Time & $\begin{array}{l}\text { Distance between } \\
\text { capture points }(\mathrm{m})\end{array}$ & $\begin{array}{c}\text { Grid disposition } \\
\text { (total capture points) }\end{array}$ & $\begin{array}{c}\text { Days of } \\
\text { sampling }\end{array}$ \\
\hline $\mathrm{CF} 1$ & Jan/99 & $8 *$ & $10 \times 6(60)$ & $3^{a}$ \\
\hline $\mathrm{CF} 2$ & Oct/01 & $8^{*}$ & $19 \times 7(133)$ & $6^{\mathrm{b}}$ \\
\hline $\mathrm{CF} 2^{1}$ & $\mathrm{Jan} / 02$ & $8 *$ & $10 \times 7(70)$ & $3^{\mathrm{b}}$ \\
\hline CF3 & Apr/02 & $8 *$ & $19 \times 7(133)$ & $6^{\mathrm{b}}$ \\
\hline $\mathrm{CF} 4^{2}$ & Aug/02 & $8 *$ & $19 \times 7(133)$ & $6^{\mathrm{b}}$ \\
\hline UF1 & Jan/99 & $8 *$ & $10 \times 6(60)$ & $3^{\mathrm{a}}$ \\
\hline UF2 & Jan/99 & $8 *$ & $9 \times 4(36)$ & $3^{\mathrm{a}}$ \\
\hline UF3 & Oct/01, Jan/02, May/02, Aug/02 & $8 *$ & $19 \times 7(133)$ & $6^{\mathrm{b}}$ \\
\hline UF3 & Oct/03 to May/04 & $8 *$ & $18 \times 8(144)$ & $5^{\mathrm{d}}$ \\
\hline UF4 & Oct/01, Jan/02, May/02 & $8 *$ & $19 \times 7(133)$ & $6^{\mathrm{b}}$ \\
\hline UF5 & $\mathrm{Jan} / 02$ & $8^{*}$ & $8 \times 4(32)$ & $4^{b}$ \\
\hline UF6 & $\mathrm{Jan} / 02$ & $8 *$ & $8 \times 4(32)$ & $4^{b}$ \\
\hline UF6 & $\mathrm{Feb} / 04$ & $10 * *$ & $8 \times 3(24)$ & $3^{e}$ \\
\hline UF7 & Jan/02 & $8 *$ & $16 \times 3(48)$ & $6^{\mathrm{b}}$ \\
\hline UF8 & Jan/02, Jun/02 & $10 *$ & $15 \times 5.4(81)$ & $3^{\mathrm{c}}$ \\
\hline UF9 & $\mathrm{Jan} / 02$ & $10 *$ & $15 \times 5.4(81)$ & $3^{c}$ \\
\hline UF10 & Jun/02 & $10 *$ & $15 \times 5.4(81)$ & $3^{\mathrm{c}}$ \\
\hline UF11 & Apr/04 & $10 *$ & $20 \times 8(160)$ & $3^{\mathrm{c}}$ \\
\hline UF12 & Nov/03 & $10 *$ & $14 \times 7(98)$ & $6^{\mathrm{d}}$ \\
\hline UF12 & Aug/04 & $10 * *$ & $14 \times 7(98)$ & $3^{e}$ \\
\hline UF13 & Jun/04 to Sep/04 & $8^{*}$ & $11 \times 11(121)$ & $5^{\mathrm{a}}$ \\
\hline UF14 & Sep/04 & $10 *$ & $10 \times 6(60)$ & $3^{e}$ \\
\hline UF14 & Nov/04 & $10 * *$ & $10 \times 6(60)$ & $3^{\mathrm{e}}$ \\
\hline UF15 & Dez/03 to May/04 & $10 *$ & $15 \times 3(45)$ & $3^{\mathrm{b}}$ \\
\hline UF16 & May/04 & $10 * *$ & $14 \times 10(140)$ & $3^{e}$ \\
\hline UF17 & Aug/04 & $10 * *$ & $10 \times 10(100)$ & $3^{e}$ \\
\hline UF18 & Nov/03 & $10 * *$ & $10 \times 3(30)$ & $3^{\mathrm{e}}$ \\
\hline UF19 & Nov/03 & $10 * *$ & $10 \times 3(30)$ & $3^{\mathrm{e}}$ \\
\hline UF20 & Nov/03 & $10 * *$ & $10 \times 3(30)$ & $3^{\mathrm{e}}$ \\
\hline UF21 & Nov/03 & $10 * *$ & $15 \times 4(60)$ & $3^{e}$ \\
\hline UF22 & Feb/04 & $10 * *$ & $10 \times 3(30)$ & $3^{\mathrm{e}}$ \\
\hline UF23 & Feb/04 & $10 * *$ & $10 \times 10(100)$ & $3^{e}$ \\
\hline UF24 & Nov/04 & $10 * *$ & $10 \times 10(100)$ & $3^{e}$ \\
\hline
\end{tabular}

*one wire mesh trap $(10 \times 10 \times 22 \mathrm{~cm})$ per capture point, ${ }^{* *}$ one snap trap per capture point.

${ }^{1}$ unlike the other CFs, there was a poorer herbaceous cover here due to the use of herbicides, ${ }^{2}$ crossed by some narrow lines $(\sim 1 \mathrm{~m})$ of a vegetation type like the UFs;

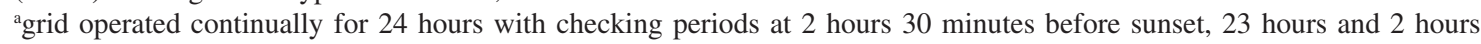
30 minutes after the sunrise.

${ }^{b}$ traps baited 2 hours 30 minutes before sunset and checked 2 hours 30 minutes after sunrise.

' grid operated continually for 24 hours with checking periods each 2 hours 45 minutes.

${ }^{d}$ traps baited 2 hours 30 minutes before sunset and checked at 23 hours and 2 hours 30 minutes after sunrise.

' grid operated continually for 24 hours with checking periods at sunset and 1 hours after sunrise.

\section{Results}

Fifteen rodent and three marsupial species were recorded through both trapping and prey consumed by White-tailed Kites and Barn Owls (Table 2). Sixteen species were sampled in traps (all vegetation types combined). Fourteen mammal species were preyed on by owls (excluding bats), and 10 by kites (Didelphis albiventris Lund, 1840, Oryzomys angouya (Fischer, 1814), Calomys sp., and Oxymycterus sp.1 were preyed on by owls, but not by kites). Four species were 
Table 2. Small mammals trapped and prey in the diet of Barn Owls (Tyto alba) and White-tailed Kites (Elanus leucurus) in Venâncio Aires, Rio Grande do Sul state, southern Brazil. Figures for small mammals consumed by owls are minimum number of specimens because we only identified right and left upper maxillaries (see details in methods).

\begin{tabular}{|c|c|c|c|c|c|}
\hline \multirow[t]{2}{*}{ Species } & \multicolumn{3}{|c|}{ Trapping (\%) } & \multicolumn{2}{|c|}{ Predator's diet (\%) } \\
\hline & $\begin{array}{c}\text { Cultivated } \\
\text { fields }\end{array}$ & $\begin{array}{c}\text { Uncultivated } \\
\text { fields }\end{array}$ & $\begin{array}{l}\text { Native forest } \\
\text { fragments }\end{array}$ & Tyto alba & $\begin{array}{c}\text { Elanus } \\
\text { leucurus }\end{array}$ \\
\hline \multicolumn{6}{|l|}{ RODENTIA } \\
\hline \multicolumn{6}{|l|}{ CRICETIDAE } \\
\hline Akodon paranaensis & $15(5.7)$ & $567(34.2)$ & $26(49.1)$ & $40(1.9)$ & $113(5.2)$ \\
\hline Euryzygomatomys spinosus & - & $7(0.4)$ & - & - & - \\
\hline Necromys lasiurus & $5(1.9)$ & $92(5.5)$ & - & $75(3.6)$ & $132(6.1)$ \\
\hline Nectomys squamipes & - & $3(0.2)$ & - & - & - \\
\hline Bruceppatersonius iheringi & - & - & $5(9.4)$ & $4(0.2)$ & $1(<0.1)$ \\
\hline Calomys sp. & - & - & - & $6(0.3)$ & - \\
\hline Holochilus brasiliensis & - & $1(<0.1)$ & - & $16(0.8)$ & $1(<0.1)$ \\
\hline Oligoryzomys nigripes & $9(3.4)$ & $123(7.4)$ & $21(39.6)$ & $105(5.0)$ & $35(1.6)$ \\
\hline Oryzomys angouya & - & $3(0.2)$ & - & $1(<0.1)$ & - \\
\hline Oxymycterus sp.1 & - & $22(1.3)$ & - & $2(0.1)$ & - \\
\hline Oxymycterus sp. 2 & - & $7(0.4)$ & - & - & - \\
\hline \multicolumn{6}{|l|}{ CAVIIDAE } \\
\hline Cavia aperea & - & $1(<0.1)$ & - & $3(0.1)$ & $37(1.7)$ \\
\hline \multicolumn{6}{|l|}{ MURIDAE } \\
\hline Mus musculus & $228(86.7)$ & $461(27.8)$ & - & $1703(81.6)$ & $1460(67.3)$ \\
\hline Rattus norvegicus & - & - & - & $1(<0.1)$ & $1(<0.1)$ \\
\hline Rattus rattus & - & $10(0.6)$ & - & $65(3.1)$ & $24(1.1)$ \\
\hline Rattus sp. & - & - & - & - & $7(0.3)$ \\
\hline Unidentified rodents & - & - & - & $27(1.3)$ & $87(4.0)$ \\
\hline \multicolumn{6}{|l|}{ MARSUPIALIA } \\
\hline Didelphis albiventris & - & $1(<0.1)$ & - & $1(<0.1)$ & - \\
\hline Gracilinanus agilis & - & $3(0.2)$ & - & - & - \\
\hline Monodelphis dimidiata & $6(2.3)$ & $358(21.6)$ & $1(1.9)$ & $13(0.6)$ & $168(7.7)$ \\
\hline \multicolumn{6}{|l|}{ CHIROPTERA } \\
\hline Molossus molossus (Pallas, 1 1766) & - & - & - & $1(<0.1)$ & - \\
\hline Tadarida brasiliensis (I. Geoffroy, 1824) & - & - & - & $6(0.3)$ & - \\
\hline Unidentified bats & - & - & - & $1(<0.1)$ & - \\
\hline AVES & - & - & - & $15(0.7)$ & $95(4.4)$ \\
\hline ANURA & - & - & - & $2(0.1)$ & - \\
\hline REPTILIA & - & - & - & - & $5(0.2)$ \\
\hline INSECTA & - & - & - & - & $4(0.2)$ \\
\hline Total specimens & $263(100)$ & $1659(100)$ & $53(100)$ & 2087 (100) & $2170(100)$ \\
\hline Richness* & 5 & 15 & 4 & 14 & 10 \\
\hline
\end{tabular}

*Refers to rodent and marsupial species.

captured in traps only (Nectomys squamipes (Brants, 1827), Euryzygomatomys spinosus (G. Fischer, 1814), Oxymycterus sp.2, and Gracilinanus agilis (Burmeister, 1854)). Rattus norvegicus (Berkenhout, 1769) appeared only in the predators' diets, and Calomys sp. was taken only by Barn Owls. The "capoeira" presented the greatest richness, being inhabited by 10 rare to relatively rare small mammal species, and five common to relatively common ones (Oligoryzomys nigripes
(Olfers, 1818), Monodelphis dimidiata (Wagner, 1847), Mus musculus Linnaeus, 1758, A. paranaensis, and $N$. lasiurus). Crop fields were widely dominated by $M$. musculus. Native forest fragments were primarily inhabited by $O$. nigripes and A. paranaensis, and secondarily by Bruceppatersonius iheringi (Thomas, 1896).

Additionally, during the study we sighted the following mammal species: Sciurus aestuans Linnaeus, 
1766, Coendou prehensilis (Linnaeus, 1758), Dasypus novemcinctus Linnaeus, 1758, Cerdocyon thous (Linnaeus, 1766), Galictis cuja (Molina, 1782), Procyon cancrivorus (G.[Baron] Cuvier,1798), Myocastor coypus (Molina, 1782), and Lepus europaeus Pallas, 1778.

\section{Discussion}

\subsection{Small mammal diversity in southern Brazil}

We found a prominent richness of terrestrial small mammals in the agricultural area in southern Brazil. Prey in the predators' diet and trapping yielded 15 native small mammals (three marsupial and 12 rodent species), besides the three introduced Old-World murides. This relatively high richness could be accounted, at least in part, to our sampling effort. Although it cannot be adequately expressed in terms of trap nights, mainly because of the highly variable checking periods among the sites sampled (see Table 1), it can be assumed that our trapping sample is well representative, especially for uncultivated fields, since it covered all seasons, at least three years, as well as many sites. The same is true for the diet of both predators. As a result, species apparently very rare in our study area such as Euryzygomatomys spinosus, Calomys sp., Oryzomys angouya, Oxymycterus sp.2, and Gracilinanus agilis were detected.

\subsection{Differences in habitat composition}

The "capoeira" supported the greatest terrestrial small mammal richness among the three habitats studied, harboring 15 species (Table 2). Five species are common to relatively common in this habitat, O. nigripes, M. dimidiata, M. musculus, A. paranaensis, and $N$. lasiurus. Although only one individual of C. aperea Erxleben, 1777 was trapped, we believe that this rodent is also relatively common in uncultivated fields, since we often saw it in these habitats. The small mammal community inhabiting "capoeiras" in southern Brazil can be understood as a mixture of species having three origins: (1) those that probably already occurred in the local native forest such as $O$. nigripes and A. paranaensis, (2) cosmopolitan exotic species, primarily M. musculus, and (3) common grassland and savanna inhabitants such as $M$. dimidiata, $N$. lasiurus, and $C$. aperea. The uncultivated fields are formed of an herbaceous stratum composed primarily of grasses, and by a poorer stratum of shrubs, mostly of Baccharis spp. Despite this relatively low structural complexity, the herbaceous stratum presents high biomass, forming a dense cover, that provides both protection against predators and availability of resources such as food and nest sites. Uncultivated fields also may be important refuges and/or foraging sites to other mammals such as D. novemcinctus, $C$. thous, and $G$. cuja, since we frequently sighted them in those habitats. Our mammal list just included those species documented by us. According to reports by local people, additional spe- cies such as other armadillos, felids, etc, may be added to the list hereafter.

The crop fields are permanently disturbed sites due to agricultural practices. Although $O$. nigripes and A. paranaensis were present, the small mammal community in these habitats was widely dominated by the exotic M. musculus, indicating its high potential in taking advantage of these structurally simple and highly disturbed habitats in southern Brazil.

Nowadays, the native formation of deciduous seasonal forest in our study area is drastically reduced and highly fragmented, having been replaced by agroecosystems. The forest fragments we sampled were extremely small ( $<1 \mathrm{ha})$ and isolated. Small mammal species that are habitat specialists or those that have low dispersal potential, leading to problems of gene flow, may be absent from these small fragments of the native forest. Note that the two most common species in forest fragments, $O$. nigripes and A. paranaensis, are common to relatively common in uncultivated and crop fields as well, attesting their high tolerance to different degrees of habitat disturbance and dispersal potential. Bruceppatersonius iheringi, on the other hand, is apparently restricted to the native forest. It is important to point out that our trapping effort in forest fragments was considerably lower than in crop fields and "capoeiras". Some species could be added to the forest fragments, increasing their richness, if more trapping was conducted. However, the rodents $O$. nigripes and $A$. paranaensis are likely the main inhabitants of these small and isolated fragments of native forest in southern Brazil.

\subsection{Trapping vs. Predators' diet for inventorying small mammals}

Our results indicated that each one of the three methods studied for inventorying small mammals in southern Brazil (prey in the diet of Barn Owls, White-tailed Kites, and trapping) presented typical peculiarities. Trapping detected 16 species, owl sampling 14 (excluding bats), and kites 10 . Four species were captured in traps only, one only by both predators, and one only by owls. Besides the species presence/absence criterion, there are other interpretations that also must be taken into account when comparing these sampling methodologies. For instance, trapping was inefficient in detecting Holochilus brasiliensis (Desmarest, 1819) and C. aperea, since only one individual of each was trapped ( $<0.1 \%$ or $1 / 1975$ specimens). On the other hand, the former would be more "easily" detected by examining the owl's diet $(0.8 \%$ or $1 / 130$ prey items) and the latter, by the kite's diet (1.7\% or $1 / 59$ prey items). Holochilus brasiliensis is a semi-aquatic species that was rare in our study area, since marshy environments are uncommon. Barn Owls are likely to be capturing it by concentrating their hunting effort in some small marshes. On the other hand, the extremely low frequency of $C$. aperea in traps cannot be due to its rarity in the study site because we often sighted it in uncultivated fields. The trap size used was possibly inappropriate to capture adults of $C$. aperea 
( $500 \mathrm{~g}$ ), but not juveniles. Thus, based on our sampling effort and the apparent abundance of $C$. aperea, it would be expected to have been more trapped if this methodology was effective to sample $C$. aperea. Another possibility is that Barn Owls and White-tailed Kites could be hunting in an area larger than our study site. However, this probably would not have changed significantly the results found here because the landscape of the region is basically the same.

Although Barn Owls caught more small mammal species than White-tailed Kites, 14 vs. 10, one of the most trapped species, the marsupial $M$. dimidiata, had very low frequency in the diet of owls $(0.6 \%)$. Kites, on the other hand, were better in sampling this marsupial (7.7\%). Such a difference was also observed in the frequency of $C$. aperea between the diet of owls and kites ( 0.1 vs. $1.7 \%$ ). Probably, one of the most important factors influencing their frequencies in the predators' diet is the difference between the activity period of the owl (nocturnal) and the kite (diurnal). Both $M$. dimidiata and C. aperea are mainly diurnal (Pine et al., 1985; González, 2001). Consequently, they should be more available for the White-tailed Kite.

Concluding, the identification of prey in the diet of Barn Owls, White-tailed Kites, and trapping were complementary methods for inventorying terrestrial small mammals in southern Brazil, since together, rather than individually, they produced a better picture of the local richness. A similar conclusion has been obtained elsewhere (Bonvicino and Bezerra (2003) by comparing prey caught by the Barn Owl with trapped samples in the cerrado of central Brazil, and Jaksić et al. (1999), by comparing prey consumed by foxes (Pseudalopex spp.), Barn Owls and trapping in the Atacama desert, Chile). Although Jaksić et al. (1981) observed that the diet of Barn Owls was a better method in central Chile compared to the diet of culpeo foxes (Dusicyon culpaeus (Molina, 1782)), Harris' hawks (Parabuteo unicinctus Temminck, 1824), and trapping.

The identification of small mammal species from the diet of Barn Owls and White-tailed Kites could be used more frequently as an alternative or additional method for inventorying terrestrial small mammals that inhabit open to moderately open environments such as fields, swamps, savannas, and deserts. These birds of prey are particularly appropriate for this purpose. Both are small mammal specialists. They can be easily found in the environment. Barn Owls often roost and nest in human buildings, where a large number of pellets and prey remains are concentrated. White-tailed Kites are conspicuous birds, easily identified by their bright plumage and characteristic hovering while hunting. Their regurgitated pellets can be obtained from roost and nest sites, as well as from communal night roosts during the non-breeding season (Morgan, 1948; Waian and Stendell, 1970). Mammalian prey remains regurgitated by both stay relatively well preserved, allowing a secure identification at a species level. Structures such as skulls could be used for revision studies on rare small mammal species or those difficultly trapped. The biogeography of a given species or genus could be better defined through its presence in the diet of these predators, since they show a wide distribution (the Barn Owl is cosmopolitan and the White-tailed Kite has Neartic and Neotropical distribution)

Acknowledgments - This work was supported by grants to D. R. Scheibler from the Fundação de Amparo à Pesquisa do Estado de São Paulo (FAPESP), processes 01/01917-8 and 04/09749-5.

\section{References}

BELLOCQ, MI., 1990. Composicion y variacion temporal de la dieta de Tyto alba en ecosistemas agrarios pampeanos, Argentina. Vida Silv. Neotrop., vol. 2, p. 32-35.

-, 2000. A review of the trophic ecology of the Barn Owl in Argentina. J. Raptor Res., vol. 34, no. 2, p. 108-119.

BONVICINO, CR. and BEZERRA, AMR., 2003. Use of regurgitated pellets of Barn Owls (Tyto alba) for inventorying small mammals in the cerrado of central Brazil. Stud. Neotrop. Fauna Environm., vol. 38, no. 1, p. 1-5.

BRASIL, 1986. Levantamento de Recursos Naturais, folha SH.22 Porto Alegre e parte das folhas SH.21 Uruguaiana e SI.22 Lagoa Mirim. Fundação IBGE, Rio de Janeiro, 791p.

CADEMARTORI, CV., FABIÁN, ME. and MENEGHETI, JO., 2004. Variações na abundância de roedores (Rodentia, Sigmodontinae) em duas áreas de floresta ombrófila mista, Rio Grande do Sul, Brasil. Rev. Brasil. Zoociências, vol. 6, no. 2, p. $147-167$.

CASTILLO, C., MARTÍN-GONZÁlEZ, E. and COELLO, JJ., 2001. Small vertebrate taphonomy of La Cueva del Llano, a volcanic cave on Fuerteventura (Canary Islands, Spain). Palaeoecological implications. Palaeogeography, Palaeoclimatology, Palaeoecology, vol. 166, no. 3-4, p. 277-291.

CLARK, DR., JR. and BUNCK, CM., 1991. Trends in North American small mammals found in common barnowl (Tyto alba) dietary studies. Can. J. Zool., vol. 69, no. 12, p. 3093-3102.

DALMAGRO, AD. and VIEIRA, EM., 2005. Patterns of habitat utilization of small rodents in an area of Araucaria forest in Southern Brazil. Austral Ecol., vol. 30, no. 4, p. 353-362.

DUNK, JR., 1995. White-tailed Kite (Elanus leucurus). In A. Poole and F. Gill (eds.), The birds of North America. The Academy of Natural Sciences, Philadelphia and The American Ornithologists' Union, Washington, DC, p. 1-15.

FAST, SJ. and AMBROSE, HW., 1976. Prey preference and hunting habitat selection in the Barn Owl. Am. Midl. Nat., vol. 96 , no. 2, p. 503-507.

GONZÁLEZ, EM., 2001. Guía de campo de los mamíferos de Uruguay. Introducción al estudio de los mamíferos. Vida Silvestre, Montevideo, 339p.

JAKSIĆ, FM., SEIB, RL. and HERRERA, CM., 1982. Predation by the Barn Owl (Tyto alba) in mediterranean habitats of Chile, Spain and California: A comparative approach. Am. Midl. Nat., vol. 107 , no. 1, p. 151-162. 
JAKSIĆ, FM., TORRES-MURA, JC., CORNELIUS, C. and MARQUET, PA., 1999. Small mammals of the Atacama Desert (Chile). J. Arid Environm., vol. 42, no. 2, p. 129-135.

JAKSIĆ, FM., YÁÑEZ, JL. and FUENTES, ER., 1981. Assessing a small mammal community in central Chile. $J$. Mammal., vol. 62, no. 2, p. 391-396.

MARTI, CD., 1988. A long-term study of food-niche dynamics in the Common Barn-Owl: comparisons within and between populations. Can. J. Zool., vol. 66, no. 8, p. 1803-1812.

MENDELSOHN, JM. and JAKSIĆ, FM., 1989. Hunting behaviour of Blackshouldered Kites in the Americas, Europe, Africa and Australia. Ostrich, vol. 60, no. 1, p. 1-12.

MORGAN, AH., 1948. White-tailed Kites roosting together. Condor, vol. 50, no. 2, p. 92-93.

PARDIÑAS, UFJ., MOREIRA, GJ., GARCIA-ESPONDA, CM. and DE SANTIS, LJM., 2000. Environmental deterioration and micromammals during the Holocene in northeastern Patagonian steppe (Argentina). Rev. Chil. Hist. Nat., vol. 73, no. 1, p. 9-21.
PINE, RH., DALBY, PL. and MATSON, JO., 1985. Ecology, postnatal development, morphometrics, and taxonomic status of the Short-tailed Opossum, Monodelphis dimidiata, an apparently semelparous annual marsupial. Ann. Carn. Mus., vol. 54, no. 6, p. 195-231.

SCHEIBLER, DR., 2004. Geographic variation in the size of mammalian prey taken by White-tailed Kites in the Americas. J. Field Ornithol., vol. 75, no. 3, p. 218-222.

SCHEIBLER, DR. and CHRISTOFF, AU., 2004. Small mammals in the diet of Barn Owls (Tyto alba) in agroecosystems of southern Brazil. Ornitol. Neotrop., vol. 15, no. 1, p. 65-70.

SCHEIBLER, DR., MENEGHETI, JO. and CHRISTOFF, AU., 2001. Predação de Elanus leucurus (Aves, Accipitridae) sobre Mus musculus (Mammalia, Muridae) e sua variação no tempo, em agroecossistema de Venâncio Aires, Rio Grande do Sul, Brasil. Bol. Soc. Biol. Concepción, vol. 72, p. 125-130.

WAIAN, LB. and STENDELL, RC., 1970. The White-tailed Kite in California with observations of the Santa Barbara population. Cal. Fish Game, vol. 56, no. 2, p. 188-198. 